\title{
Coinfection by Toxoplasma gondii and Leishmania spp. in domestic cats (Felis catus) in State of Mato Grosso do Sul
}

\author{
Audrey Rennó Campos Braga ${ }^{[1]}$, Ana Paula Ferreira Lopes Corrêa ${ }^{[2]}$, Lucilene Granuzzio Camossi ${ }^{[2]}$, \\ Rodrigo Costa da Silva ${ }^{[2]}$, Helio Langoni ${ }^{[2]}$ and Simone Baldini Lucheis ${ }^{[3]}$
}

[1]. Instituto Mineiro de Agropecuária, Uberaba, MG. [2]. Departamento de Higiene Veterinária e Saúde Pública, Faculdade de Medicina Veterinária e Zootecnia, Universidade Estadual Paulista, Botucatu, SP. [3]. Agência Paulista de Tecnologia dos Agronegócios, Bauru, SP.

\begin{abstract}
Introduction: Leishmaniasis and toxoplasmosis are important to public health. Methods: Antibodies for Toxoplasma gondii and Leishmania spp. were evaluated in cats from Campo Grande, State of Mato Grosso do Sul, Brazil, a region endemic for canine visceral leishmaniasis. Serum samples from 50 asymptomatic cats were titrated for $T$. gondii by the immunofluorescence antibody test and modified agglutination test and for Leishmania spp. by the immunofluorescence antibody test. Results: These two agents coinfected two (4\%) of the 50 tested animals. Conclusions: These findings demonstrate the concomitant presence of two important zoonoses in cats from Brazilian endemic regions for canine visceral leishmaniasis.
\end{abstract}

Keywords: Cats. Leishmania species. Toxoplasma gondii.

Toxoplasma gondii and Leishmania spp. are protozoan parasites that cause zoonosis, are distributed worldwide, and affect domestic and wild animals and humans. Cats are important in the epidemiology of toxoplasmosis because they are the only hosts that can excrete the environmentally resistant stage: the oocysts ${ }^{1}$.

In 1999, visceral leishmaniasis in cats was first recorded by Hervas et al. ${ }^{2}$ in Spain. Since then, current cases represent a widespread distribution, and include reports from Italy ${ }^{3}$, Portugal $^{4}$, the United States ${ }^{5}$. In Brazil, the first occurrence of Leishmania infantum in a cat was recorded in 2004 by Savani et $\mathrm{al}^{5}$. Some authors consider this animal an accidental host, while others suggest that felids can act as potential peridomestic reservoirs ${ }^{6}$. However, the role of cats in the epidemiology of leishmaniasis remains to be clarified.

The present study was approved by the Animal Ethics Committee (protocol 65/2007) of the School of Veterinary Medicine and Animal Husbandry, São Paulo State University, following the Ethical Principles in Animal Experimentation. A total of 50 cats (Felis catus) that were domiciliated in the City of Campo Grande $\left(20^{\circ} 26^{\prime} 34^{\prime \prime} \mathrm{S}, 54^{\circ} 38^{\prime} 47^{\prime \prime} \mathrm{W}\right)$ in the State of Mato Grosso do Sul, Brazil were selected randomly without predilection for sex breed, or age. Blood samples were obtained to detect antibodies for T. gondii and Leishmania spp.

\footnotetext{
Address to: Profa. Simone Baldini Lucheis. APTA Polo Centro Oeste. Av. Rodrigues Alves 40-40, 17030-000 Bauru, SP, Brasil.

Phone: 5514 3203-3257; Fax: 5514 3281-4391

e-mail: silucheis@apta.sp.gov.br; lucilenecamossi@gmail.com

Received 21 February 2014

Accepted 3 June 2014
}

The immunofluorescence antibody test (IFAT) was performed, according to the method described by Camargo ${ }^{7}$, which used whole Leishmania major-like promastigote and the RH strain of T. gondii as the antigen for the diagnosis of leishmaniasis and toxoplasmosis, respectively. Modified agglutination test (MAT) using the RH strain was performed, as described by Desmonts and Remington ${ }^{8}$. The cutoff $T$. gondii antibody titer for both tests was 16, and the corresponding value in IFAT for Leishmania spp. was 40.

Two (4\%) of the 50 animals presented titers of antibodies for T. gondii and Leishmania spp., which suggested coinfection by these two protozoa in the same animal. Cat \#1 was a female of undefined breed, 2 years of age, and presented $T$. gondii antibody titers of 64 (based on IFAT) and 1,024 (based on MAT), and an antibody titer of 320 for Leishmania spp. Cat \#2 was also a female of undefined breed, 3 years of age, and presented T. gondii titers of 16 (based on IFAT) and 1,024 (based on MAT), and a Leishmania spp. titer of 320 (Table 1). Neither cat presented clinical signs. Similar results were obtained by Cardia et al. ${ }^{9}$ with specific anti-Toxoplasma immunoglobulin $\mathrm{G}(\mathrm{IgG})$ in $63(16.3 \%)$ of 386 cats and $\mathrm{IgG}$ against Leishmania spp. in two serum samples with titers of 1:160 and 1:320, respectively. In a study conducted by Sobrinho et al. ${ }^{10}$ in another Brazilian endemic area, $25.7 \%$ cats were coinfected with both agents. However, the authors did not observe a significant association between these infections.

In this study, the MAT and IFAT were used, based on the results for cats obtained by Macrì et al. ${ }^{11}$, with a concordance of 0.98 (i.e., nearly perfect), an MAT sensitivity of $97.8 \%$ and specificity of $100 \%$, and using IFAT as the gold standard test. In conclusion, coinfection by $T$. gondii and Leishmania spp. occurs in cats in Brazil in regions endemic or epidemic for canine 
TABLE 1 - Antibody titers in the immunofluorescence antibody test and modified agglutination test against Toxoplasma gondii and Leishmania spp. in two naturally infected cats from Campo Grande, State of Mato Grosso do Sul, Brazil.

\begin{tabular}{lcccc}
\hline & \multicolumn{2}{c}{ Toxoplasma gondii } & & Leishmania spp. \\
\cline { 2 - 3 } Animal & IFAT & MAT & & IFAT \\
\hline Cat \#1 & 64 & 1,024 & 320 \\
Cat \#2 & 16 & 1,024 & 320 \\
\hline
\end{tabular}

IFAT: immunofluorescence antibody test; MAT: modified agglutination test.

visceral leishmaniasis. Serological surveys may be useful for understanding zoonosis dissemination in urban environments. More detailed studies are needed to clarify the role of cats in the epidemiology of leishmaniasis (e.g., as reservoirs or accidental hosts for dogs and humans) to prevent and control zoonosis in these endemic regions.

\section{ACKNOWLEDGMENTS}

The authors wish to thank the Center for Control of Zoonoses for the City of Campo Grande, State of Mato Grosso do Sul for help with the animals and for blood collection.

\section{CONFLICT OF INTEREST}

The authors declare that there is no conflict of interest.

\section{FINANCIAL SUPPORT}

This research was supported by the São Paulo Research Foundation [Fundação de Amparo à Pesquisa do Estado de São Paulo (FAPESP)]; process number: 2007/56395-2).

\section{REFERENCES}

1. Dubey JP, Su C, Cortés JA, Sundar N, Gomez Marin JE, Polo LJ, et al. Prevalence of Toxoplasma gondii in cats from Colombia, South America and genetic characterization of T. gondii isolates. Vet Parasitol 2006; 141:42-47.

2. Hervas J, Chacón M de Lara F, Sáchez-Isarria MA, Pellicer S, Carrasco L, Castillo JA, et al. Two cases of feline visceral and cutaneous leishmaniasis in Spain. J Feline Med Surg 1999; 1:101-105.

3. Poli A, Abramo F, Barsotti P, Leva S, Gramiccia M, Ludovisi A, et al. Feline leishmaniosis due to Leishmania infantum in Italy. Vet Parasitol 2002; 106:181-191.

4. Maia C, Nunes M, Campino L. Importance of cats in zoonotic leishmaniasis in Portugal. Vector-Borne Zoon Dis 2008; 8:555-559.

5. Savani ES, Camargo MCO, De Carvalho MR, Zampieri RA, Dos Santos MG, D'Auria SR, et al. The first record in the Americas of an autochthonous case of Leishmania (Leishmania) infantum chagasi in a domestic cat (Felix catus) from Cotia County, São Paulo State, Brazil. Vet Parasitol 2004; 120:229-233.

6. Martín-Sánchez J, Acedo C, Munoz-Pérez M, Pesson B, Marchal $\mathrm{O}$, Morrilas-Marquez F. Infection by Leishmania infantum in cats: epidemiological study in Spain. Vet Parasitol 2007; 145:267-273.

7. Camargo ME, Rebonato C. Cross-reactivity in fluorescense tests for Trypanosoma and Leishmania antibodies. Am J Trop Med Hyg 1969; 18:500-505.

8. Desmonts G, Remington JS. Direct agglutination test for diagnosis of Toxoplasma infection: method for increasing sensitivity and specificity. J Clin Microbiol 1980; 11:562-568.

9. Cardia DF, Camossi LG, Neto LS, Langoni H, Bresciani KD. Prevalence of Toxoplasma gondii and Leishmania spp. infection in cats from Brazil. Vet Parasitol 2013; 197:634-637.

10. Sobrinho LSV, Rossi CN, Vides JP, Braga ET, Gomes AAD, Lima VMF, et al. Coinfection of Leishmania chagasi with Toxoplasma gondii, feline immunodeficiency virus (FIV) and feline leukemia Virus (FeLV) in cats from an endemic area of zoonotic visceral leishmaniasis. Vet Parasitol 2012; 187:302-306.

11. Macrì G, Sala M, Linder A, Pettirossi N, Scarpulla M. Comparison of indirect fluorescent antibody test and modified agglutination test for detecting Toxoplasma gondii immunoglobulin G antibodies in dog and cat. Parasitol Res 2009; 105:35-40 